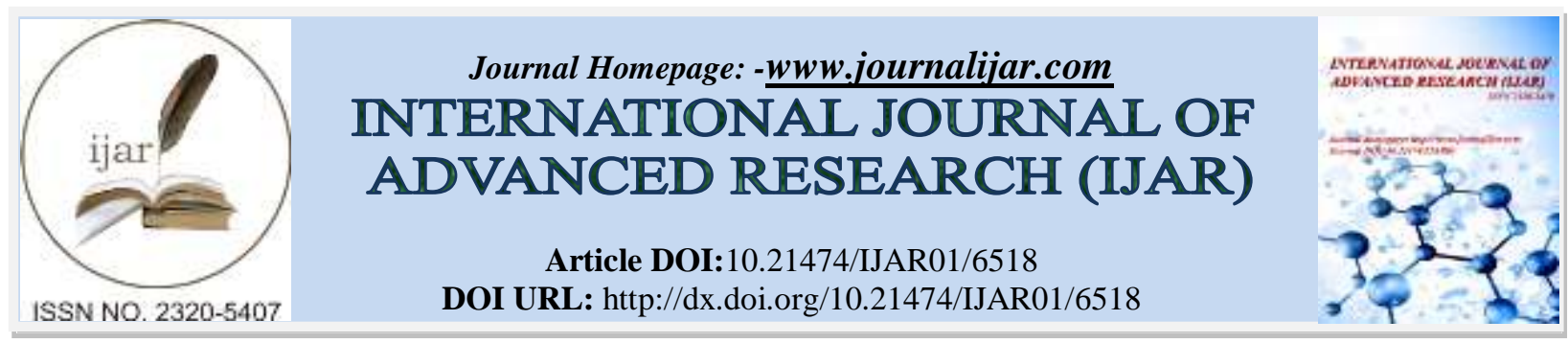

RESEARCH ARTICLE

\title{
PREVALENCE AND SEVERITY OF SUB-CLINICAL MASTITIS IN LACTATING COWS: DETECTION BY SURF FIELD MASTITIS TEST.
}

\author{
Ranjeet S. Tanwar, Vikas Sarsar, Neha Soni and Anami Ahuja. \\ Department of Biotechnology, N.C College of Engineering, Israna (Panipat), India.
}

\section{Manuscript Info}

Manuscript History

Received: 13 December 2017

Final Accepted: 15 January 2018

Published: February 2018

Keywords:-

Milk, SCM, Surf Field Mastitis

Test,Intramammary Infection.

\section{Abstract}

A total number of one hundred cow milk samples were examined in the present study for the Sub-clinical mastitis. In our study $44 \%$ milk samples were found positive for Surf Field Mastitis Test (SFMT). Quarter wise infection rate was found to be $18.5 \%$ and $31.5 \%$ in fore and hind-quarters respectively. According to the IDF criteria, 14.17, 18.33 and $8.35 \%$ quarters had subclinical, latent and non specific mastitis, respectively. Incidence of sub-clinical mastitis was assessed in dairy cows kept under different farm management conditions in two villages of Panipat district, Haryana. The prevalence of mastitis in cows were determined by examination of changes in the udder viz., swelling, redness and hardness of udder, changes in milk colour and reduction in quality of the milk. Further, pH testing of the milk and Surf Field Mastitis Test (SFMT) was done to confirm the subclinical mastitis.

Copy Right, IJAR, 2018,. All rights reserved.

\section{Introduction:-}

Mastitis is an inflammatory condition of the udder. It is characterized by physical, chemical and microbiological changes in the milk. It poses the risk for transmission of many zoonotic diseases like tuberculosis, leptospirosis, brucellosis, streptococcal sore throat and gastroenteritis (Radostits et al., 1994). It has also been indicated that mastitis is an important cause of premature culling (Samiullah et al., 2000). Mastitis represents a serious problem to be considered due to the economic loss for which it is responsible (Ahmad, 2001). The SCM usually goes unnoticed because the milk and udder appear normal. Sub-clinically infected quarters can develop clinical mastitis and the rate of new infections can be high (Zdunczyk et al., 2003). Sub-clinical mastitis causes two third loss of the total milk production due to affected quarters of animal (Radostits et al., 2007). At present, it is one of the most economically important diseases worldwide (Chishty et al., 2007 and Hashemi et al., 2011) and the most important economical factor affecting the dairy animals worldwide (Ali et al., 2011). This dairy scourge not only reduces the milk yield of affected animals (nearly 15 to $20 \%$ ) but also renders the milk unsuitable for human consumption (Ghulam Muhammad and Imaad Rashid, 2012). The sub-clinical or hidden form of mastitis is 15-40 times more common than clinical mastitis. Clinical cases are preceded by the hidden form of mastitis. An early diagnosis of hidden mastitis is imperative to save the udder and prevent transmission of disease-producing organisms to other animals in the herd. It is also important from the public health viewpoint as the milk of animals affected with sub-clinical mastitis contains disease producing bacteria, their toxins, abnormal milk constituents as well as pus cells. Inflammation of the parenchyma of mammary gland takes place in mastitis (Souto et al., 2010). Proteus spp., Salmonella spp. and Bacillus spp. have been isolated from milk samples collected from goats suffering from mastitis (Iqbal et al., 2004). Streptococcus spp., Staphylococcus spp., Pasteurella spp. and E. coli were also reported (Contreras et al., 2007). 
Staphylococcus aureus, Streptococcus spp. and E. coli revealed in milk collected from subclinical mastitis were found to be 61, 15 and 5 percent, respectively (Aydin et al., 2009). Staphylococcus aureus had been reported as most frequent etiological agent $(45.34 \%)$ in cases of dairy goat mastitis (Ali et al., 2010). Major organisms causing infection are Staphylococci spp., Streptococci spp. and gram-negative bacteria (Mubarack et al., 2012). Diagnosis in clinical as well as sub-clinical cases largely depends on the presence of significantly higher leukocytes count in the milk from affected glands. In context of milk, these leukocytes are called somatic cells. It may be mentioned here that the sub-clinical mastitis is reasonable for greater pecuniary loss to the farmers than its clinical counterpart. In Sub-clinical mastitis (SCM) there are no much visible abnormalities in udder tissues except an elevated Somatic Cell Count (SCC) (MacDougall et al., 2001). The effective prevention and etiological therapy of this disease requires precise bacteriological diagnosis along with sensitivity testing of microbial agents against various antimicrobials (Malinowski et al., 2002). Concurrent resistance of bacterial species to antimicrobials of different classes is increasing in multitude and complicating the therapeutic management of infections (Iqbal et al., 2002). Such bacterial pathogens which are not responding to more than two antibiotic classes in therapeutic dose are considered multiple drug resistant (MDR). It is one of the emerging problems of mastitis causing bacteria (Hameed et al., 2007). The presence of multiple drug resistant bacteria in cow or goat mastitis milk deteriorates its quality. Use of such milk may lead to the transfer of resistance to normal flora of consumers. The Clinical Mastitis (CM) is usually accompanied by physical, chemical, pathological and bacteriological changes both in milk and glandular tissues (Samad, M.A. 2008)). Maintaining hygiene with antimicrobial therapy plays an impotant role in mastitis control by reducing the levels of herd infection (Unakal et al., 2010). Among different available tests, California Mastitis Test (CMT) (Contreras et al., 1995), White Slide Test (WST) (Kahir, M.A. 2006) and Surf Field Mastitis Test (SFMT) (Muhammad et al., 1995) are considered as simple, easily applicable, rapid indirect screening tests for determining SCM. Reagents of these tests contain detergents which change the structure and conductivity of cell membrane and nucleus of somatic cells, stimulate proteolytic enzymes, and increase milk viscosity (Middleton et al., 2004). Sensitivity of a clinical test refers to the ability of the test to correctly identify those patients with the disease and specificity refers ability to correctly identify those patients without the disease (Lalkhen et al., 2013). Haryana is one of the top-ten states in milk production and may be considered as the milk pocket of India. There was no much information on Haryana based study for SCM. Therefore, the present study was conducted to detect the prevalence and severity of sub-clinical mastitis in lactating cows using indirect screening tests i.e. SFMT.

\section{Materials and Methods:-}

Present study was carried out on bovine sub-clinical mastitis in cow, in Village Israna and Mundlana (Panipat) India. After explaining the objectives of the study, consent was taken from all participating farmers and information on age, lactation stage and previous history of mastitis was collected. Both commercial and backyard dairy cows from rural areas were selected randomly. A total number of one hundred ( $1^{\text {st }}$ to $5^{\text {th }}$ lactation) milk samples of cows aged between 5-10 years were obtained and considered for this study. Standard mastitis control measures such as post milking antiseptic teat dipping and dry period antibiotic therapy were not practiced in these cows.

\section{Milk sampling:-}

Quarter fore-milk samples were collected aseptically for assay as described by Haltia and Honkanen-Buzalski et al., (2006). Prior to collection of milk samples, the udder was washed with water and dried with paper towel. Teat ends were disinfected with cotton swabs soaked in $70 \%$ ethanol and allowed to dry. The first streams of milk were discarded. Milk samples of the respective quarters of an animal were collected in sterile 15 ml tubes and properly marked with number of animal and position of quarter. The milk samples were then transported in an ice box to the laboratory for further testing and analysis.

\section{Physical examination of milk sample:-}

Immediately after collection, milk samples were subjected to physical examination with naked eyes to detect any abnormalities in colour, odour, consistency and presence of clot, blood, flakes and any other visible abnormalities (Muhammad Shahidet al., 2011).

\section{Indirect screening tests:- pH determination:-}

In this study $\mathrm{pH}$ was used as one of the important parameter as the indicator of mastitis. Normal milk $\mathrm{pH}$ is $6.6-6.7$ where as milk with higher $\mathrm{pH}$ indicated the positive test for mastitis (Bachaya H.A. et al., 2011). 


\section{Surf field mastitis test:-}

The samples were subjected to Surf Field Mastitis test (SFMT). The principle of the test is that when detergent is added into milk sample, it causes rupture of somatic cells, releases DNA and other cell contents. DNA is acidic in nature, while detergent contains alkyl-arylsulfonate, which is basic in nature. Combination of DNA and detergent resulted into a gel. Consistency of gel depends upon the number of somatic cells. Higher the number of cells, thicker gel formation and vice-versa.

\section{Special attributes of Surf Field Mastitis Test:-}

It is easy to conduct due to user friendly nature of the test and less time consuming, having good sensitivity (72.81 and 66.22 in cows and buffaloes respectively) of detection vis-à-vis other tests like California Mastitis Test (75.73 and 70.27 cows and buffaloes respectively (Muhammad et al., 2010) and the gold standard of mastitis diagnosis i.e. microbiological examination of aseptically collected milk samples. The test reagent, i.e. Surf Excel Powder (Unilever Ltd.) is easy available in almost every village.

\section{Procedure:-}

3\% Surf solution $(\mathrm{pH}=10.3)$ was prepared by dissolving 3 grams of commonly available Surf Excel (Uniliver, India) in $100 \mathrm{ml}$ of Distilled water. This test solution is stable for six months at room temperature. Equal quantity of $3 \%$ reagent and milk were mixed in a sterile conical flask. The mixture is swirled for about 1 minute and then poured into a petri plate. After a few seconds, visual examination for the presence of floccules or gel formation indicated the positive results for intra mammary infection. While absence of any floccules or gel formation in the sample, was considered negative.

The changes in consistency of milk indicated mastitis, while no change in consistency of milk indicated healthy samples. The mastitis was graded into further four categories based on the severity of disease from lower to higher intensity as, +(moderate), ++(severe), +++( more severe), ++++(very severe) (Muhammad et al., 1995; Fazal-urRehman, 1995). The percentage of prevalence was calculated by using the following formula as- Prevalence $(\%)=$ No. of samples positive /No. of samples tested x 100

\section{Microbial Culture:-}

Collected milk samples were primarily cultured on blood agar using 'spread out technique' as described by Lafi and Hailat (1998). The plates were incubated for $24 \mathrm{hrs}$ at $37^{\circ} \mathrm{C}$. Bacterial growth was purified by streaking. Gram's staining was performed to study the morphology of bacteria. Pure bacterial cultures were identified on the basis of cultural, morphological and biochemical characteristics (John, 2000).

\section{Results:-}

Mastitis in cows were determined by examination of changes in the udder viz., swelling, redness and hardness of udder, changes in milk colour and reduction in quality of the milk. An increase in the $\mathrm{pH}$ of milk was observed which indicated the subclinical mastitis. Further, Surf Field Mastitis Test (SFMT) of milk samples was performed to confirm the subclinical mastitis. In our study on cow milk samples, 44 out of 100 i.e. (44\%) quarters were found to be positive for SFMT. Thus the prevalence of SCM by SFMT was $44 \%(\mathrm{n}=100)$. Among these infected quarters, $19 \%$ were right fore, $25 \%$ right hind, $18 \%$ left fore and $38 \%$ left hind quarters. Mean value of sub-clinical mastitis was higher $(31.5 \%)$ in hindquarters of cows in comparison to $(18.5 \%)$ in fore-quarters. Thus, there was higher incidence in hindquarters. Among hindquarters, left hindquarters were found to be slightly more susceptible (38\%). In case of fore-quarters, right fore-quarters were found to be more susceptible (19\%), as also reported by Saini et al. (1994). Incidence of sub-clinical mastitis was found to be highest in the early stage of lactation (52\%) followed by mid (31\%) and late stage of lactations (17\%). In present study, Staphylococcus aureus was isolated as top ranking pathogen from cases positive for mastitis. In previous studies, it was also reported as major pathogen (Kapur et al., 1992; Allore, 1993; Rabello et al,. 2005; Arshad et al., 2006; Ebrahimi et al., 2007; Ali et al., 2008; Botrel et al., 2009). According to a report $70-80 \%$ of all the clinical and subclinical mastitis cases were either infected with Staphylococcus aureus or Streptococcus agalactiae in cows and buffaloes (Memon et al., 1999).

Table and Graph-1:-Prevalence of Sub-Clinical Mastitis in Cows Detected by Surf Field Mastitis Test

\begin{tabular}{|c|c|c|c|c|c|c|c|}
\hline & & \multicolumn{5}{|c|}{ Grading of gel } & \\
\hline $\begin{array}{c}\text { Testing } \\
\text { Method } \\
\text { Used }\end{array}$ & $\begin{array}{c}\text { Total No. } \\
\text { of Milk } \\
\text { Samples }\end{array}$ & $(+)$ ve \% & $(++)$ ve \% & $\begin{array}{c}(+++) \text { ve } \\
\%\end{array}$ & $\begin{array}{c}(++++) \text { ve } \\
\%\end{array}$ & $(-)$ ve \% & $\begin{array}{c}\text { Overall } \\
\text { Prevalence } \\
\text { (SCM) \% }\end{array}$ \\
\hline
\end{tabular}




\begin{tabular}{|c|c|c|c|c|c|c|c|}
\hline & Tested & & & & & & \\
\hline SFMT & 100 & 31 & 9 & 3 & 1 & 56 & 44 \\
\hline
\end{tabular}

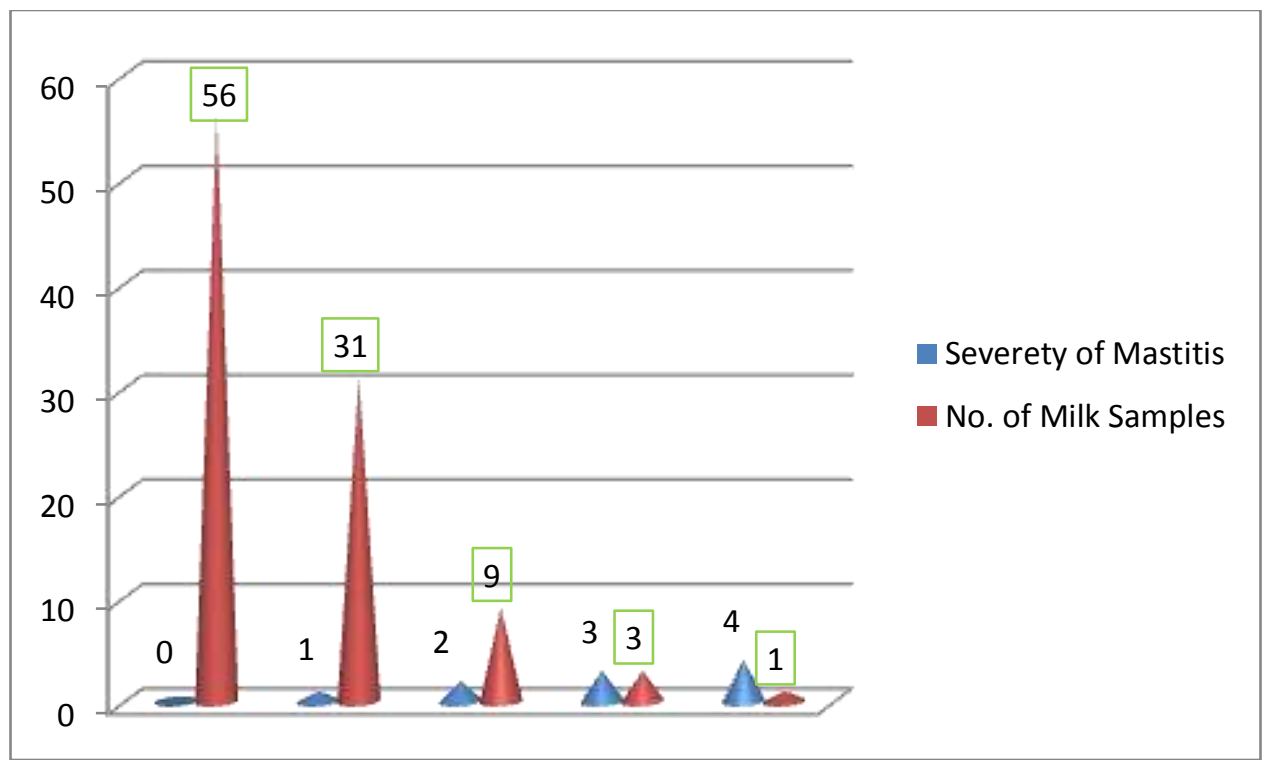

Table and Graph-2:-Mastitis Incidence (Percentages) in Cows in Different Stages of Lactation

\begin{tabular}{|c|c|c|}
\hline S.N. & Lactation Stage & Mastitis Incidence (\%) \\
\hline 1 & Early & 52 \\
\hline 2 & Mid & 31 \\
\hline 3 & Late & 17 \\
\hline
\end{tabular}

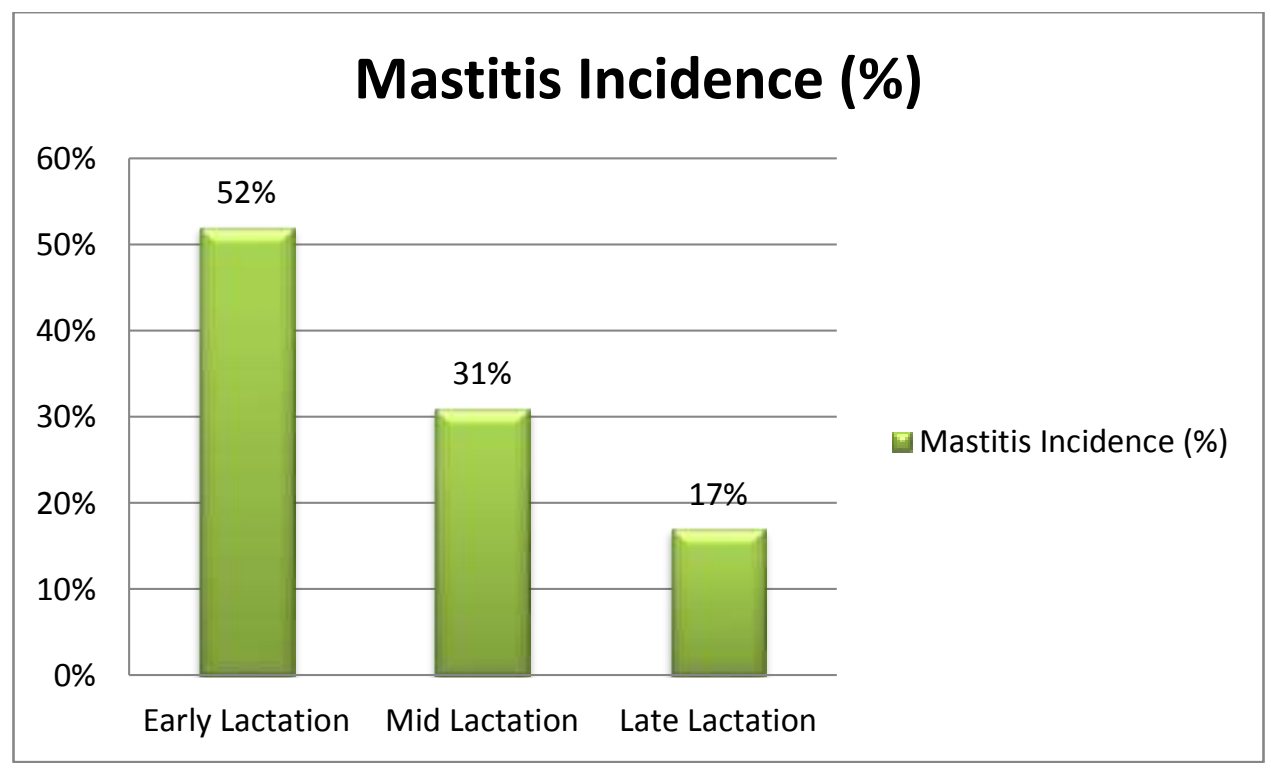

Table and Graph-3:-Quarterwise Mastitis Incidence (Percentages) in Cows

\begin{tabular}{|c|c|c|}
\hline S. N. & Quarters & Mastitis Incidence (Percentages) \\
\hline 1. & Right Fore Quarters & $19 \%$ \\
\hline 2. & Right Hind Quarters & $25 \%$ \\
\hline 3. & Left Fore Quarters & $18 \%$ \\
\hline 4. & Left Hind Quarters & $38 \%$ \\
\hline
\end{tabular}




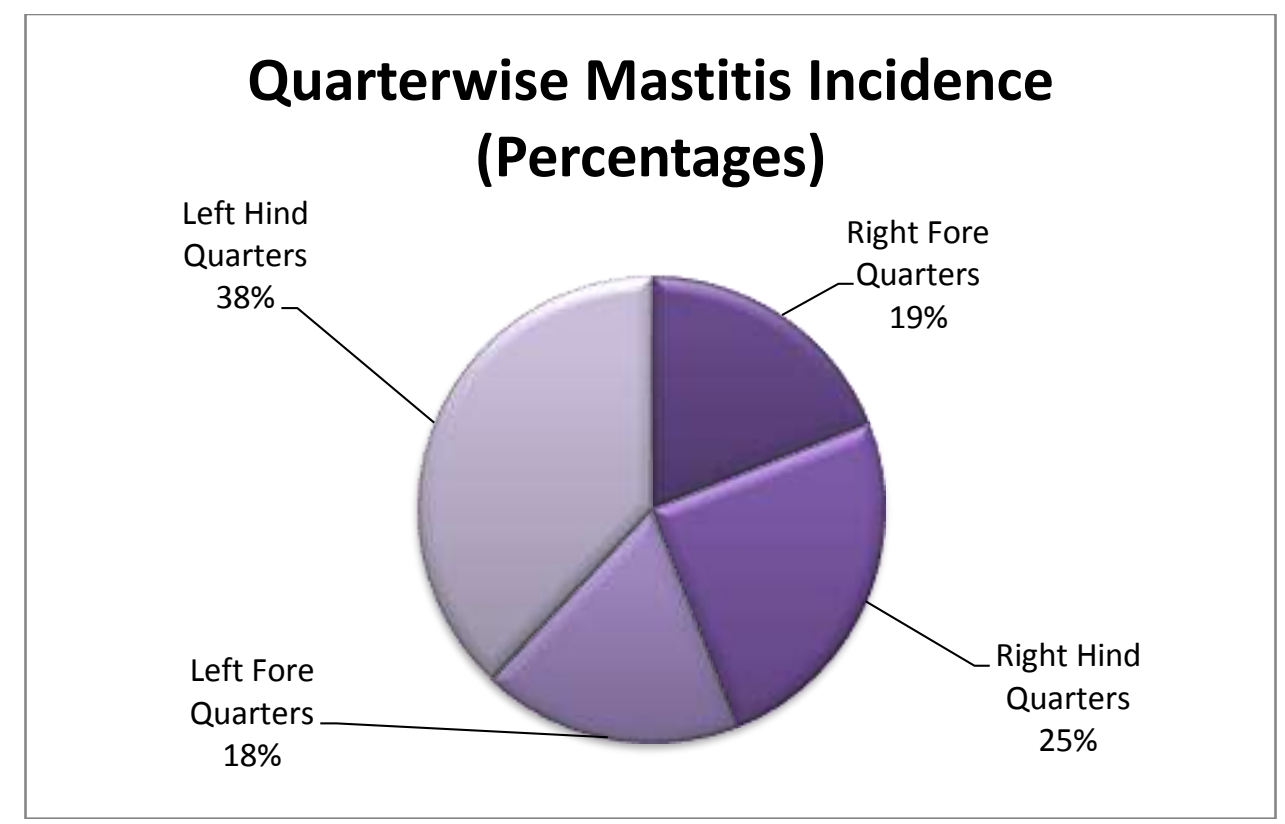

Table and Graph-4:-Mean Value of Sub-Clinical Mastitis Incidence (\%) in Fore and Hind Quarters of Cows

\begin{tabular}{|c|c|}
\hline Quarters & Quarterwise Mastitis Incidence (Percentages) \\
\hline Fore Quarters & $18.50 \%$ \\
\hline Hind Quarters & $31.50 \%$ \\
\hline
\end{tabular}

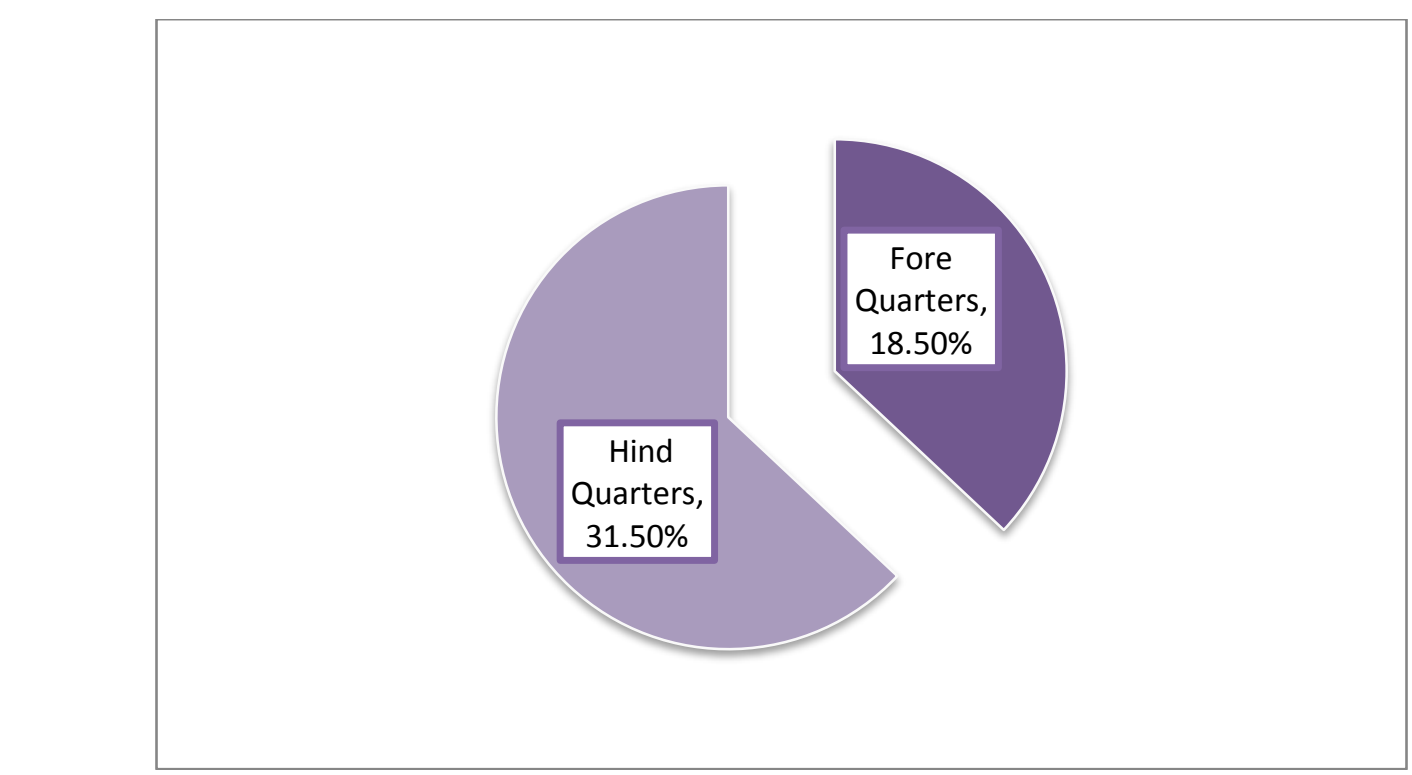

Interestingly, Mean value of sub-clinical mastitis was higher (31.5\%) in hindquarters of cows in comparison to $(18.5 \%)$ in fore-quarters. 


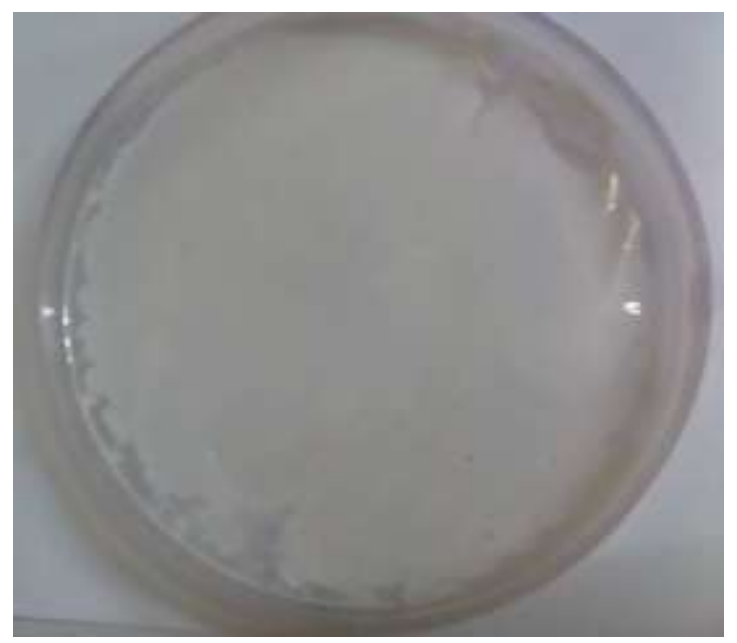

Figure 1:- Milk sample showing moderate intensity of sub-clinical mastitis

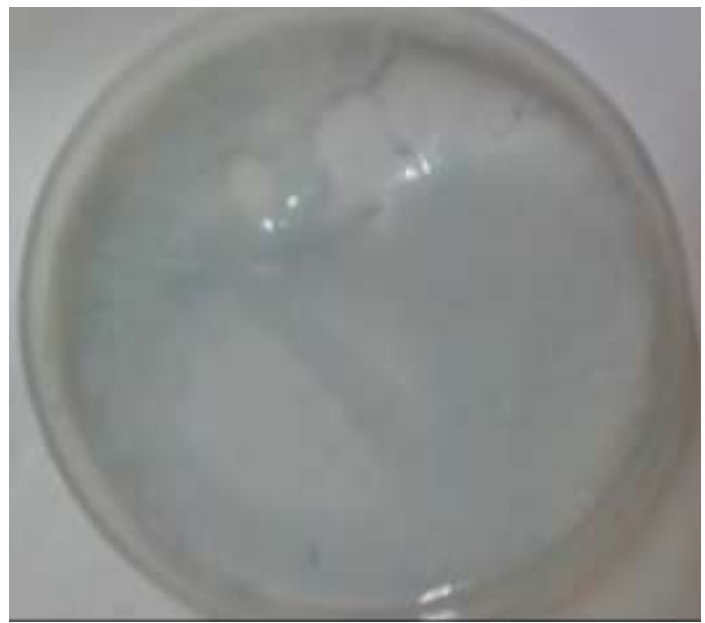

Figure 2:- Milk sample showing high intensity of sub-clinical mastitis

\section{Discussion:-}

Overall prevalence of SFMT was 44\% (Table-1). The prevalence was almost nearer to the findings of (Kader et al., 2003 and Islam, et al., 2010) who had reported $46.6 \%$ and $36.46 \%$ in lactating dairy cows. Higher prevalence was reported by (Motice, et al., 1985) and lower prevalence was reported by (Rahman, et al., 2009). Difference in prevalence of SCM might be due to climatic factors (humidity, temperature, seasonal variations), geographical locations, difference of breed, management systems and other associated conditions. Several studies have reported increased mastitis with the advancing parity (Prodhan, et al., 1996). It has been shown that high-yielding dairy cows are more prone to mastitis as the glandular tissues are more susceptible to infection (Radostits, et al., 2000). Interestingly, high parity cows are more productive, and it is likely that cows with advancing parity are prone to mastitis. It is reported that the prevalence of mastitis is often high in last stage of pregnancy followed by a marked decline after parturition (Radostits, et al., 2000). Our results are also in agreement to these findings. There are some multiple drug resistant (MDR) pathogens responsible for causing mastitis in dairy goats. Milk consumed from these goats suffering from clinical or sub-clinical mastitis may transmit antibiotic resistance genes to micro flora of human beings. This situation may be a biggest human beings health hazard (M. F. Najeeb et al., 2013).

Quaterwise infection rate was found to be $16 \%$ and $28 \%$. In a similar study, Saluja et al. (2004) reported infection rate of $31.3 \%$ in a dairy herd. In an earlier study, the percentages of the cows (and quarters) with SCM were found to be $43.8 \%(24.3 \%)$ when assessed by cultural examination (Karimuribo et al., 2008). Out of 5707 quarter milk samples, $1070(18.74 \%)$ and $1878(32.90 \%)$ samples were found positive for clinical and subclinical mastitis, respectively (Sharma and Sindhu, 2007). The high prevalence in the present study could be attributed to a group of 
factors such as poor habitat, lack of hygiene, unavailability of balanced food and climatic conditions. These factors might have played a role in rendering the udder more prone and susceptible to intra mammary infections (Ghazi and Niar, 2006).

It had been found earlier that the sensitivity of the different tests viz. CMT, SCC, WST and SFMT were $80.08 \%$, $86.60 \%, 60.54 \%$ and $57.47 \%$; specificity $69.40 \%, 97.81 \%, 63.38 \%$ and $60.66 \%$. Percentage accuracy of these tests was $75.68 \%, 91.22 \%, 61.71 \%$ and 58.78. Quarter-wise sub-clinical mastitis (SCM) was detected in 59.68\%, $51.80 \%, 50.68 \%$ and $50 \%$ samples by CMT, SCC, WST and SFMT, respectively, while animal-wise SCM was recorded in $72.07 \%, 66.67 \%, 64.86 \%$ and $61.26 \%$ samples by CMT, SCC, WST and SFMT, respectively. Moreover, the right hind quarters were found most significantly susceptible to SCM than other quarters. Cows with 3rd and 4th parity and at their early lactation stage had significantly higher $(\mathrm{p}<0.001)$ SCM than others (M. Badiuzzaman et al., 2015).

Only cells possessing nuclei interact with superficial active agents. During interaction between detergents and nuclei of somatic cells DNA is released, which increases milk viscosity (Sargeant et al., 2001, Ruegg and Reinemann, 2002 and Middleton et al., 2004). The tests work best in a weakly alkaline medium, where changes in mixture are maintained for more than 15 minutes. This may explain the linear relationship between mastitis test results and somatic cell count in milk. Higher leukocytes count was detected in milk of affected animals (Radostits et al., 2006).

According to Department of Animal Husbandry, Dairying \& Fisheries, Ministry of Agriculture, GOI, milk production in India is increasing every year for last fifteen years. Thus it may be hoped that milk production will improve many folds in coming years by timely detection and treatment of SCM.

\section{Conclusion:-}

Mastitis is a common problem of dairy industries. Reduction in milk production and an irreparable damage to the udder associated with the disease are the common causes of culling of dairy cows. Milk from infected animals is not suitable for human consumption and for making different milk products. So it has a major economic importance in dairy cattle. The prevalence of sub-clinical mastitis increases in cows with a history of periparturient disease, cows without dry cow therapy, high milk producing cows and cows with the advancing age. This study recommends that regular screening of sub-clinical mastitis will reduce the prevalence of sub-clinical mastitis. The most effective way to control sub-clinical mastitis is to take preventive measures such as milkman's cleanliness, regular cleaning of the udder and floor, dry cow therapy especially in high yielding dairy cows. SFMT are easily applicable and cost effective tests for regular screening of sub-clinical mastitis. As there is no vaccine for mastitis, hygiene should be maintained at every aspect of dairy farms. Care and management should be improved. Infected milk should be properly disposed by adding 5\% phenol. All the equipments and containers should be cleaned and washed properly. The SCM usually goes unnoticed, it is important to screen a particular dairy herd for this disease at regular intervals so as to adopt an effective treatment. This would also prevent us from serious economic loss.

\section{Acknowledgements:-}

The authors are thankful to Department of Biotechnology, N.C College of Engineering, Israna (Panipat) for support and providing fund for this research work. The authors also would like to thank all staff members and farmers for there valuable support. 


\section{References:-}

1. Ahmad, R., (2001): Studies on mastitis among dairy buffaloes. Pakistan. Vet. J., 21(4): 220-221.

2. Ali, G., M. Arshad, M. Saqib and I. J. Hassan, (2008): Bacteriology of mastitis in buffaloes in tehsil Samundri of district Faisalabad, Pakistan. Pakistan Vet. J., 28(1): 31-33.

3. Ali, Z., G. Muhammad, T. Ahmad, R. Khan, S. Naz, H. Anwar, F.A. Farooqi, M.N. Manzoor, and A. R. Usama (2010): Prevalence of Caprine subclinical mastitis, its etiological agents and their sensitivity to antibiotics in indigenous breeds of Kohat, Pakistan. Pakistan J. Life Soc. Sci., 8(1): 63-67.

4. Ali, M. A., M. D. Ahmad, K. Muhammd, and A. A. Anjum (2011): Prevalence of subclinical mastitis in dairy buffaloes of Punjab, Pakistan. J. Anim. Plant Sci., 21(3): 477-480.

5. Allore, H. G., (1993): A review of the incidence of mastitis in buffaloes and cattle. Pakistan Vet. J., 13: 1-7.

6. Arshad, M., G. Muhammad, M. Siddique, M. Ashraf and H. A. Khan, (2006): Staphylococcal Mastitis in Bovines and some properties of Staphylococcal Isolates. Pakistan Vet. J., 26(1): 20-22.

7. Aydin, I., K. Kav and H.A. Celik (2009): Identification and antimicrobial susceptibility of subclinical mastitis pathogen isolated from Hair goats milk. J. Anim. Vet. Adv., 8: 1086-1090.

8. Ayyasamy manimaran, Siddartha S. Layek, A. Kumaresan, Shiv Prasad, Sreela, V. Boopathi, Kausal Kumar and V. Venkatasubramanian (2014): Estimation of antimicrobial rug usage for treatment of clinical mastitis cases in organized dairy farm.Ind. J. Vet \& anim. Sci. Res., 43(2): 140-150.

9. Bachaya H.A, Raza M.A, Murtaza.S, and Akbar I.U.R (2011): Subclinical Bovine Mastitis in Muzaffar Garh District of Punjab (Pakistan), The Journal of Animal \& Plant Sciences, 21: 16-19.

10. Barua M, Prodhan MAM, Islam K, Chowdhury S, Hasanuzzaman M, Imtiaz MA and Das GB (2014): Subclinical mastitis prevalent in dairy cows in Chittagong district of Bangladesh: detection by different screening tests, Veterinary World, 7(7): 483-488.

11. Botrel, M. A., M. Haenni, E. Morignat, P. Sulpice, J. Y. Madec and D. Calavas, (2009): Distribution and antimicrobial resistance of Clinical and Subclinical Mastitis Pathogens in Dairy Cows in Rhône-Alpes, France. Foodborne Pathog. Dis., 7(5): 479-487.

12. Chishty, M.A., Arshad, M., Avais, M. and Ijaz, M. (2007): Cross-sectional epidemiological studies on mastitis in cattle and buffaloes of tehsil Gojra Pakistan,Buffalo Bulletin, 26(2): 50-55.

13. Contreras, A., Correlas, J.C., Sierra, D. and Marco, J. (1995): Prevalence and aetioloogy of nonclinical intramammary infection in murciano-granadian goats. Small Ruminant Research, 17(1): 71-78.

14. Contreras, A., D. Sierra, A. Sanchez, J.C. Corrales, J.C. Marcoc, M.J. Paape, and C. Gonzalo (2007): Mastitis in small ruminants. Small Ruminant Research, 68: 145-153.

15. Dua, K. (2001): Incidence, aetiology and estimated loss due to mastitis in India-Anupdate. Indian Dairyman, 53: 41-48.

16. Ebrahimi, A., K. H. P. Kheirabadi and F. Nikookhah (2007): Antimicrobial susceptibility of environmental bovine mastitis pathogens in west central Iran. Pakistan J. Biol. Sci., 10 (17): 3014-6.

17. Fazal-ur-Rehman (1995): Studies on I) Evaluation of surf field mastitis test for the detection of subclinical mastitis in buffaloes and cattle, II) Antibiotic susceptibility of pathogens. M. Sc. Thesis, Deptt: Vet. Clinical Medicine and Surgery, Univ. Agri. Faisalabad, Pakistan.

18. Ghazi, K. and Niar, A. (2006): Incidence of mastitis in various bovine breeding in Tiaret area (Algeria). Assiut Vet. Med. J., 52: 198.

19. Ghulam Muhammad and Imaad Rashid (2012): Case Report- a new horizon in farmer's level early detection of hidden mastitis using the innovative surf field mastitis test: Buffalo Bulletin, 31(3): 105-110.

20. Haltia and Honkanen-Buzalski et al; (2006): A study of bovine mastitis, milking procedures and management practices on 25 Estonian dairy herds. Acta Veterinaria Scandinavica, 48: 22

21. Hameed, K.G.A., G. Sender, and A.K. Kossakowska (2007): Public health hazard due to mastitis in dairy cows. Anim. Sci. Pap. Rep., 26 (2): 73-85.

22. Hashemi, M., Kafi, M. and Safdarian, M. (2011): The prevalence of clinical and subclinical mastitis in dairy cows in the central region of Fars province, south of Iran Iranian Journal of Veterinary Research,12(3): 36

23. Iqbal, M., I. K. Patel, Q. Ain, N. Barney, Q. Kiani, K.Z. Rabbani, G. Zaidi, B. Mehdi and S.H. Shah (2002): Susceptibility pattern of Escherichia coli: Pervalence of multidrug-resistant isolates and extended spectrum Beta-Lactamase phenotype. J. Pakistan Med. Associ., 52(9): 407-411.

24. Iqbal, M., M.A. Khan, B. Daraz and U. Siddique (2004): Bacteriology of mastitic milk and in vitro antibiogram of the isolates. Pakistan Vet. J., 24(4): 161-164.

25. Islam, M.A., Rahman, A.K.M.A., Rony, S.A. and Islam, M.S. (2010): Prevalence and risk factors of mastitis in lactating dairy cows at Baghabari milk shed area of Sirajganj. Bangladesh Journal of Veterinary Medicine, 8(2): $157-162$. 
26. John, G. H. (2000): Bergey's manual of determinative bacteriology. Actinomycetales. 9th ed. Williams and Wilkins, Baltimore

27. Kader, M. A., M. A. Samad, and S. Saha. (2003): Influence of host level factors on prevalence and economics of subclinical mastitis in dairy milch cows in Bangladesh. Indian Journal of Dairy Science, 56(4): 235-240.

28. Kahir, M.A. (2006): Across sectional epidemiological study on subclinical mastitis of dairy cows in Sylhet. MS Thesis., Department of Medicine, Bangladesh Agricultural University, Ymensingh, Bangladesh.

29. Kapur, M. P., Anshusharma and R. M. Bahardwal, (1992): Bacteriology of clinical mastitis in buffaloes. Buffalo Bull., 11: 32-35.

30. Karimuribo, E. D., Fitzpatrick, J. L, Swai, E. S., Bell, C., Bryant, M. J., Ogden, N. H., Kambarage D. M. and French N. P. (2008): Prevalence of subclinical mastitis and associated risk factors in smallholder dairy cows in Tanzania. Vet. Rec., 163: 16-21.

31. Lafi, S. Q. and N. Q. Hailat (1998): Bovine and ovine mastitis in Dhuleil valley of Jordan. Veterinarski Arhiv., 68: 51-57.

32. Lalkhen, A. G., McCluskey, A. (2013): Clinical tests: sensitivity and specificity. Oxford Journals, Medicine \& HealthBJA: CEACCP 8(6): 221-223.

33. M. A. Ali, M. D. Ahmad, K. Muhammad and A. A. Anjum (2011): Prevalence of Sub Clinical Mastitis in Dairy Buffaloes of Punjab, Pakistan. The Journal of Animal \& Plant Sciences, 21(3): 477-480.

34. MacDougall, S.P., Murdough, W., Pankey, C., Delaney, Barlow, J. and Scruton, D. (2001): Relationships among somatic cell count, California mastitis test, impedance and bacteriological status of milk in goats and sheep in early lactation.Small Ruminant Research, 40(3): 245-254.

35. Malinowski, E., A. Klossowska, M. Kaczmarowski, H. Lassa, and K. Kuzma (2002): Antimicrobial susceptibility of Staphylococci isolated from affected with mastitis cows. Bull. Vet. Inst. Pulawy, (46): 289-294.

36. M. Badiuzzaman, M. A. Samad, S. H. M. F. Siddiki, M. T. Islam1 and S. Saha (2015): Bangl. J. Vet. Med., 13(2): 41-50.

37. Mahenthiran R. and Michael A. (2016): Isolation and identification of microorganisms from bovine mastitis infected milk samples and their antibiogram. World Journal of Pharmaceutical Research, 5(02): 1238-1247.

38. Memon, M. I., K. B. Mirbahar, M. R. Memon, N. Akhtar, S. A. Soomoro and P. Dewani, (1999): A study on the etiology of subclinical mastitis in buffaloes. Pakistan J. Agri. Agri. Engg. Vet. Sci., 15: 34-36

39. M. F. Najeeb, A. A. Anjum, M. U. D. Ahmad, H. M. Khan, M. A. Ali, and M. M. K. Sattar (2013): Bacterial etiology of subclinical mastitis in dairy goats and multiple drug resistance of the isolates. The Journal of Animal \& Plant Sciences, 23(6): 1541-1544.

40. Middleton, John.R., Hardin, D., Steevens, B., Randle, R. and Tyler, J. (2004): Use of somatic cell counts and California mastitis test results from individual quarter milk samples to detect subclinical intramammary infection in dairy cattle from a herd with a high bulk tank somatic cell count. Journal of the American Veterinary Medical Association, 224(3) (2004): 419-423.

41. Motice, A., Ramudit, S. and Mohabir, R. (1985): Subclinical mastitis in dairy cattle in Guyana.Tropical Animal Health and Production, 17(4): 245-246.

42. Mubarack, H.M., Doss, A., Vijayasanthi, M. and Venkataswamy, R. (2012): Antimicrobial drug susceptibility of from subclinical bovine mastitis in Coimbatore, Tamilnadu, South India. Veterinary World, 5(6): 352-355.

43. Muhammad, G., Athar, M., Shakoor, A., Khan, M. Z., Fazalur- Rehman andAhmad M.T. (1995): Surf Field Mastitis Test: An inexpensive new tool for evaluations of wholesomeness of fresh milk. Pakistan Journal of Food Science 5: 91-93.

44. Muhammad, G. Naureen, A., Sadiq, M., and Fazal-ur- Rehman (2010): Evaluation of a 3\% surf solution (surf field mastitis test) for the diagnosis of subclinical bovine and bubalinemastitis. Am. J.Vet. Res., Iran J. Vet. Res., Trop. Anim. Health Prod., 42(3): 457-464.

45. Muhammad Shahid, NaveedSabir, Ishtiaq Ahmed, Raj Wali Khan, Muhammad Irshad, Muhammad Rizwan and Sajjad Ahmed(2011): Diagnosis of Subclinical Mastitis in Bovine Using Conventional Methods and Electronic Detector, ARPN Journal of Agricultural and Biological Science, 6: 18-22.

46. Prodhan, M. A. M., and A. H. M. Kamal. "Mahbub-E-Elahi ATM (1996): Prevalence of sub-clinical mastitis in cows of Baghabari Milkshed area. Bangladesh Veterinary Journal, 30: 59-61.

47. Rabello, R. F., C. R. V. M. Souza, R. S. Duarte, R. M. M. Lopes, L. M. Teixeira and A. C. D. Castro, (2005): Characterization of Staphylococcus aureus isolates recovered from bovine mastitis in rio de janeiro, Brazil. American Dairy Science Assoc., 234-345.

48. Radostits, O. M., D. C. Blood and C. C. Gay, (1994): Veterinary Medicine, $8^{\text {th }}$ ed., Bailliere Tindall, London, 563-614. 
49. Radostits, O.M., Gay, C.C., Blood, D.C. and Hinchcliff, K.W. (2000): Mastitis. In: 9 ed., Saunders, Edinburg, 603-622

50. Radostits, O.M., C.C. Gay, D.C. Blood, and K.W. Hinchcliff (2006): Mastitis of Goats. Veterinary Medicine- A textbook of the disease of cattle, sheep, pigs, goats and horses. 10th Ed. W.B. Saunders Co; Philadelphia, USA: 761-762.

51. Radostits, O. R., D. C. Blood and C. C. Gay, (2007): Mastitis. Veterinary Medicine: A textbook of the diseases of cattle, horses, sheep, pigs and goats, 9th Edn., Bailer tindall, London: 563-614.

52. Rahman, M. A., Bhuiyan, M.M.U., Kamal, M.M. and Shamsuddin, M. (2009): Prevalence and risk factors of mastitis in dairy cows.Bangladesh Veterinarian, 26(2): 54-60.

53. Saini, S. S., J. K. Sharma and M. S. Kwatra, (1994): Prevalence and etiology of subclinical mastitis among crossbred cows and buffaloes in Punjab. Indian J. Dairy Sci., 47: 103-106.

54. Saluja, P.S., Gupta, S.L, Kapur, M.P. and Sharma, A. (2004): Prevalence of the bovine mastitis in an organized dairy herd. Indian Vet. J., 84: 1404-1405.

55. Samad, M.A. (2008): Animal Husbanry and Veterinary Science, LEP pub no.11, Bangladesh Agricultural University campus, Mymensingh, 2: 1184-1189

56. Sammiullah, M.U.D. Syed, M. Arif and M. Khan, (2000): Frequency and causes of culling and mortality in Holstein Friesian cattle in NWFP (Pakistan). J. Anim. Hlth. Prod., 20: 22-24.

57. Sharma, A. and Sindhu N. (2007): Occurrence of clinical and subclinical mastitis in buffaloes in the State of Haryana (India). Ital. J. Anim. Sci., 6: 965-967

58. Souto, Luis.I., Minagawa, C.Y., Telles, E.O., Garbuglio, M.A., Amaku, M., Melville, P.A., Dias, R.A., Sakata, S.T. and Benites, N.R. (2010): Correlation between mastitis occurrence and the count of microorganisms in bulk raw milk of bovine dairy herds in four selective culture media. Journal of dairy research, 77(01): 63-70.

59. Supriya, Vivek Saxena and Deepika Lather (2010): Prevalence of subclinical mastitis in an organized cow herd: Haryana vet. 49, 64-65.

60. Thrusfield, M. (2005): Criteria for Success of Questionnaire. In: Veterinary Epidemiology, 3 ed., Blackwell Science, Oxford, UK, 189-213.

61. Unakal, C.G. and Kaliwal, B.B. (2010): Prevalence and antibiotic susceptibility of from bovine mastitis. 3(2): 65-6

62. Vytautas Špakauskas, Irena Klimienè, and Algimantas Matusevičius(2006): A comparison of indirect methods for diagnosis of subclinical mastitis in lactating dairy cows: Vet. Arhiv, 76 (2): 101-109

63. Z. Khan and G. Muhammad (2005): Quarter-Wise Comparative Prevalence of Mastitis In Buffaloes And Crossbred Cows, Pakistan Vet. J., 25(1) 9-12.

64. Zdunczyk, S., Zerbe, H. and Hoedemaker, M. (2003): Importance of oestrogen and estrogen-active compounds for udder health in cattle: A review. Dtsch Tierarztl Wochenschr.110: 461. 